\title{
Keefektifan penggunaan Dua Jenis Ovitrap untuk Pengambilan Contoh Telur Aedes spp. di Lapangan
}

\author{
NUR ENDAH WAHYUNINGSIH, MURSID RAHARDJO, \\ DAN TAUFIK HIDAYAT \\ Bagian Kesehatan Lingkungan Fakultas Kesehatan Masyarakat \\ Universitas Diponegoro
}

(diterima November 2008, disetujui Juni 2009)

\begin{abstract}
The effectiveness of two different ovitraps for Aedes spp. egg collections in the field. In the last three decades, there has been a four fold increase of dengue incidence globally. Up till now, the control of the disease depends heavily on controlling the vector. Therefore, it is necessary to develop an ecological data of vector to identify the population density of the mosquitoes. One method to study the density and presence of the mosquitoes is through the use of ovitrap. The aim of this research is to identify the effect of two different types of ovitraps: natural and artificial ovitrap on the willingness of mosquitoes to lay eggs and the rate of which the eggs are hatched. One hundred and eighty ovitrap consist of coconut shell (90) and glass (90) ovitrap were placed in three different subdistricts which was selected based on the Incidence Rate of Dengue Haemorrhagic Fever (DHF) in the district of Purwokerto City. The container indices and eggs density were compared between two types of ovitrap. Research was conducted using experimental quasy and the data were analyzed with the Mann-Whitney test. The total amount of eggs from coconut shell ovitrap were 9328 of eggs were obtain from 51.33 of (57\%) ovitrap while the total amount of eggs from glass ovitrap only 1858 of eggs were obtain from 29 $(32 \%)$ ovitrap. Statistical test showed significant difference between the amount of eggs of coconut shell higher than the glass with $p=0001$. Mosquitoes prefer natural coconut shell ovitrap compared with artificial ovitrap so we recommended that to eradicate the mosquitoes nest (PSN) with $3 \mathrm{M}$ (closed, drain, bury) should not only artificial containers but also natural container to be managed in order to control the dengue vector.
\end{abstract}

KEYWORDS: Natural, artificial ovitrap, preference to hatch Aedes sp. eggs

\section{PENDAHULUAN}

Angka kesakitan karena infeksi virus dengue di dunia meningkat sampai empat kali selama 3 dekade terakhir. Vektor utamanya, Aedes aegypti, sudah tersebar di seluruh negara tropis. Kira-kira terjadi 50 juta infeksi demam berdarah di lebih dari 100 negara setiap tahun. Komplikasi seperti demam berdarah dengue (DBD) dan dengue shock syndrom biasanya muncul ketika seseorang terinfeksi oleh 2 serotipe virus. Tidak ada obat yang spesifik dan tidak ada vaksin yang tersedia untuk demam berdarah. 
Penanggulangan penyakit ini sangat tergantung pada upaya pengendalian vektornya.

Telah diketahui bahwa nyamuk dapat bertelur pada tempat yang mengandung air seperti lubang pohon, tanaman air di dalam pot, tatakan pot bunga, penyimpan air di kebun dan taman, penampung air terbuka, penampung air besar yang tidak mudah dikuras seperti drum penampung air, drum bekas penampung air, drum bekas aspal di pinggir jalan serta talang air dan sampah yang dapat menampung air (WHO, 2005 dan Jackman \& Olson, 2008).

Kabupaten Banyumas merupakan salah satu kabupaten di Jawa Tengah. Kabupaten ini dalam tiga bulan pertama tahun 2006 memiliki penderita DBD yang meningkat cukup besar, yaitu dari 132 kasus pada tahun 2005 menjadi 329 kasus di awal tahun 2006. Wilayah endemi DBD juga meluas, dari 21 desa pada tahun 2005 menjadi 27 desa pada tahun 2006. Kasus paling tinggi terjadi di Kota Purwokerto. Di kota ini masih didapati kebiasaan tidak tertib dalam membuang sampah seperti membuang botol bekas, kaleng, tempurung kelapa dan sampah lain penampung air yang dapat menjadi breeding place (tempat perindukan) nyamuk. Hal ini berpotensi meningkatkan angka kesakitan DBD. Untuk itu perlu dipahami lebih dahulu ekologi vektor, diantaranya kesukaan nyamuk dalam memilih tempat untuk bertelur.
Tujuan penelitian ini adalah membandingkan jumlah telur dan indeks ovitrap yang diperoleh dari ovitrap tempurung kelapa dan gelas kaca di lapangan.

\section{BAHAN DAN METODE}

\section{Survei lokasi}

Survei umum mengenai lokasi Kota Purwokerto dilakukan sebelum penelitian dimulai. Tiga kecamatan terpilih mewakili daerah dengan incidence rate (IR) DBD kecamatan yang tinggi, sedang, dan rendah. Penentuan tinggi-rendah IR DBD kecamatan didasarkan atas angka IR DBD kecamatan dari seluruh kota kemudian ditentukan yang terendah dan tertinggi lalu dikelompokkan menjadi tiga sehingga didapatkan wilayah kecamatan yang termasuk kategori IR DBD tinggi, sedang dan rendah. Data IR diambil dari Dinas Kesehatan Kabupaten Banyumas 20022006. Tiga kecamatan tersebut berturut turut adalah Kecamatan Purwokerto Selatan yang memiliki IR 3,63, Kecamatan Purwokerto Timur dengan IR 3,12 dan Kecamatan Purwokerto Barat dengan IR 2,19 per 10.000 penduduk. Setelah itu, pada tiga kecamatan masing-masing dipilih satu lokasi kelurahan yang mewakili posisi geografis terhadap Kota Purwokerto, sehingga didapat tiga kelurahan yaitu Karangklesem (Kec. Purwokerto Selatan), Arcawinangun (Kec. Purwokerto Timur), dan Kober (Kec. Purwo- 
kerto Barat) sebagai wilayah penelitian.

\section{Ovitrap}

Ovitrap merupakan sebuah alat yang terdiri dari sebuah tempat penampung air dengan kertas saring untuk tempat nyamuk meletakkan telur. Alat ini digunakan untuk mendeteksi populasi Aedes. Ovitrap terdiri dari dua jenis tempat penampung air yaitu gelas kaca (ovitrap buatan) dan tempurung kelapa (ovitrap alami). Ovitrap tempurung kelapa adalah sisa batok kelapa tua berbentuk setengah bola yang dibeli dari pedagang burung, dan merupakan tempat makan burung yang bersih. Ovitrap gelas kaca adalah gelas kaca bening dengan volume 200 $\mathrm{ml}$. Kedua jenis ovitrap diisi $3 / 4$ volume masing-masing dengan air sumur setempat. Kedalam kedua jenis ovitrap, dimasukkan kertas saring berbentuk persegi panjang, dipasang melingkar sisi dalam ovitrap. Sisi samping ovitrap diganjal dengan batu agar tidak terguling. Pengawasan ovitrap dilaksanakan dua hari sekali selama satu minggu pada bulan Mei 2007 di tiga wilayah studi.

Sembilan puluh ovitrap gelas kaca dan sembilan puluh ovitrap tempurung kelapa ditempatkan secara acak di 3 lokasi kelurahan pada breeding places nyamuk Aedes. Tiap kelurahan terdapat 30 titik lokasi penempatan ovitrap terdiri dari 10 lokasi di dalam rumah, yaitu di bagian rumah yang gelap misalnya di balik lemari, di bawah meja dan lain-lain, dan 20 lokasi di luar rumah. Lokasi di luar rumah terdiri dari lokasi kebun dan bantaran sungai yaitu di tempat yang sebagian atau seluruhnya terlindung dari sinar matahari, dan di tempat yang cocok bagi nyamuk untuk beristirahat dan bertelur. Ovitrap diletakkan di atas tanah dan dihindarkan dari gangguan anak-anak. Setiap titik lokasi terdiri dari 2 jenis ovitrap yaitu satu ovitrap tempurung kelapa dan satu ovitrap gelas kaca. Karena siklus gonotropik nyamuk setiap $2-3$ hari maka dalam penelitian ini ovitrap diambil setiap 2 hari dan diganti dengan kertas saring serta air yang baru untuk mencegah adanya telur yang menumpuk pada kertas saring.

Ketentuan pemasangan ovitrap menggunakan bantuan peta berukuran 1: 5000 untuk menentukan satu titik pusat pada ovitrap yang akan diletakkan di dalam rumah, di kebun dan bantaran sungai pada tiap kelurahan terpilih (30 buah). Setiap ovitrap berjarak 100-600 meter untuk menghindarkan telur berasal dari tetua yang sama.

Kertas saring dikeringkan selama kurang lebih 5 jam kemudian dimasukkan ke dalam tas dan dibawa ke laboratorium. Telur pada kertas saring dihitung dan diidentifikasi di bawah mikroskop di Laboratorium Parasitologi B2P2VRP Salatiga oleh seorang ahli dengan menggunakan mikroskop binokuler. Dari pemeriksaan ini di- 
peroleh data tentang jenis dan jumlah telur nyamuk.

\section{Analisis data}

Untuk mengevaluasi banyaknya telur di wilayah penelitian, dihitung rerata jumlah telur di dalam ovitrap (jumlah total telur di ovitrap dibagi jumlah total ovitrap) dan ovitrap indeks (OI) (jumlah ovitrap positif dibagi jumlah total ovitrap x 100\%). Uji normalitas data dilakukan dengan Shapiro-Wilk sedangkan uji beda dengan Mann-Whitney pada taraf signifikansi 0,05 .

\section{HASIL DAN PEMBAHASAN}

Hasil identifikasi telur menunjukkan hanya ditemukan telur genus Aedes sp. dan tidak ditemukan telur dari nyamuk genus lain. Jumlah telur Aedes sp. dari ovitrap tempurung kelapa sebanyak 9328 butir sedangkan jumlah telur dari ovitrap gelas kaca sebanyak 1858 butir. Gelas kaca hanya berisi $19,9 \%$ telur dibandingkan tempurung kelapa. Perolehan total telur di daerah IR tinggi paling banyak dibandingkan dengan di dua kecamatan yang lain.

Tabel 1. memperlihatkan ovitrap tempurung kelapa yang positif sebanyak $51,33(57 \%)$ dibandingkan dengan 29 buah $(32 \%)$ ovitrap gelas kaca. Ovitrap index tempurung kelapa 1,8 kali lebih banyak dibandingkan ovitrap index gelas kaca. Gambar 1 dan Tabel 1 menunjukkan bahwa indeks ovitrap dan jumlah telur Aedes terbanyak ditemukan di Kelurahan Karangklesem. Namun, rerata jumlah telur tiap ovitrap tempurung kelapa memperlihatkan terbanyak di Kelurahan Arcawinangun (Tabel 2). Di antara tiga lokasi penelitian, Kelurahan Karangklesem terletak paling rendah dari permukaan laut dan mewakili wilayah dengan IR kecamatan tertinggi. Hasil penelitian ini sesuai dengan hasil Boesri et al. (1995) yang mendapatkan bahwa semakin rendah suatu daerah pemukiman akan semakin tinggi kepadatan populasi $A$. aegypti dan A. albopictus.

Tabel 1. Indeks Ovitrap tempurung kelapa dan gelas kaca di tiga kelurahan di Kota Purwokerto. 2007

\begin{tabular}{|c|c|c|c|c|c|c|c|c|}
\hline \multirow{3}{*}{ Jenis ovitrap } & \multirow{2}{*}{\multicolumn{2}{|c|}{$\begin{array}{c}\text { Karangklesem } \\
\text { (T) } \\
\text { Ovitrap }\end{array}$}} & \multirow{2}{*}{\multicolumn{2}{|c|}{$\begin{array}{l}\text { Arcawinangun } \\
\text { (S) } \\
\text { Ovitrap }\end{array}$}} & \multirow{2}{*}{\multicolumn{2}{|c|}{$\begin{array}{c}\begin{array}{c}\text { Kober } \\
\text { (R) }\end{array} \\
\text { Ovitrap }\end{array}$}} & \multicolumn{2}{|c|}{ Total } \\
\hline & & & & & & & & \\
\hline & $\left.f^{*}\right)$ & $\%$ & f*) & $\%$ & $\left.f^{*}\right)$ & $\%$ & $\left.\Sigma \mathrm{f}^{*}\right)$ & $\%$ \\
\hline $\begin{array}{l}\text { Tempurung } \\
\text { kelapa }\end{array}$ & 19 & 63,33 & 17 & 56,67 & 15.33 & 51,11 & 51,33 & 57 \\
\hline Gelas kaca & 15,67 & 52,22 & 7 & 23,33 & 6,33 & 21,11 & 29 & 32 \\
\hline
\end{tabular}




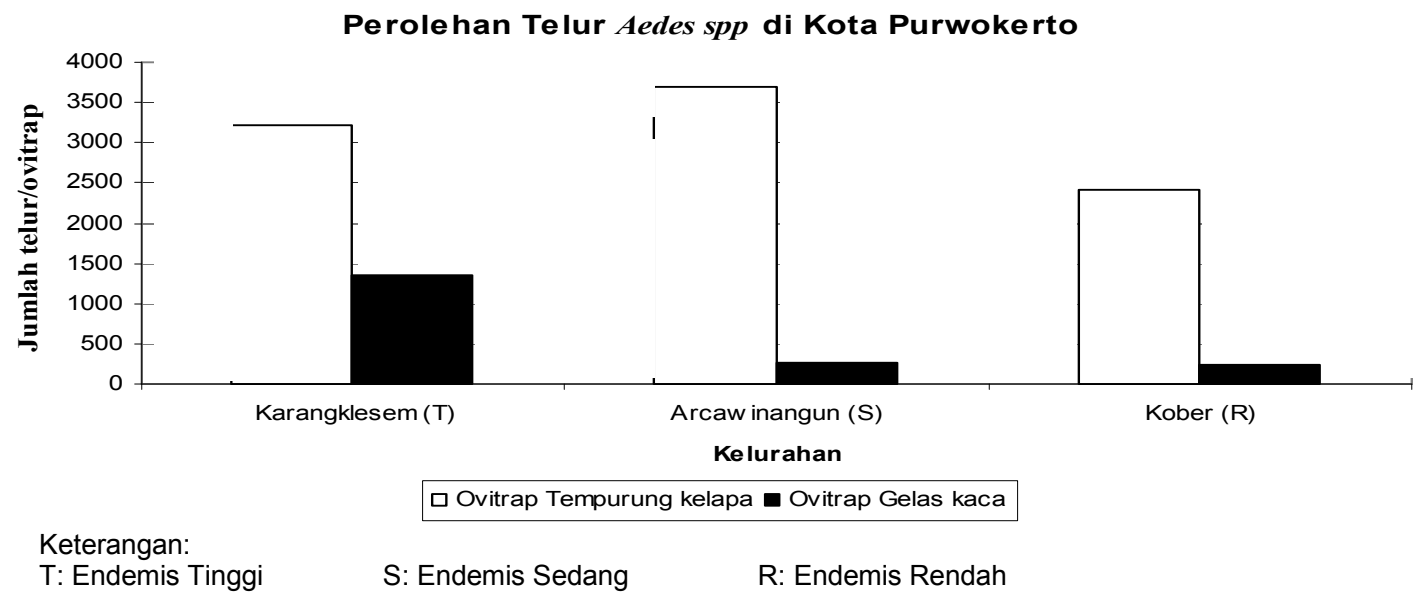

Gambar 1. Perolehan Telur Aedes spp. di Kota Purwokerto.

Tabel 2. Rerata jumlah telur per ovitrap di tiga Kelurahan di Kota Purwokerto. 2007

\begin{tabular}{lcccc}
\hline \hline Jenis Ovitrap & Lokasi & Karangklesem (T) & Arcawinangun (S) & Kober (R) \\
\hline Tempurung kelapa & Rumah & 45,0 & 40,8 & 39,5 \\
& Kebun & 66,0 & 59,6 & 52,7 \\
& Sungai & 52,0 & 90,1 & 55,0 \\
\hline \multirow{2}{*}{ Gelas kaca } & Rerata & 54,3 & 63,5 & 49,1 \\
& Rumah & 17,7 & 9,0 & 9,5 \\
& Kebun & 33,8 & 13,6 & 11,6 \\
& Sungai & 26,5 & 14,0 & 13,3 \\
\hline & Rerata & 26,0 & 12,2 & 11,4 \\
\hline
\end{tabular}

Tabel 3. Kondisi lingkungan di 3 (tiga) Kelurahan di Kota Purwokerto tahun 2007

\begin{tabular}{lccc}
\hline \hline \multicolumn{1}{c}{ Kondisi Lingkungan } & Karangklesem $(\mathrm{T})$ & Arcawinangun $(\mathrm{S})$ & Kober $(\mathrm{R})$ \\
\hline Ketinggian $(\mathrm{m}$ dpl) & 62,5 & 87 & 75 \\
Suhu $\left({ }^{\circ} \mathrm{C}\right)$ & $18-31$ & $20-30$ & $22-32$ \\
Kelembaban $(\%)$ & $70-85$ & $75-85$ & $75-85$ \\
\hline
\end{tabular}

Ketiga lokasi, berdasarkan suhu dan kelembaban (Tabel 3) memenuhi syarat perkembangbiakan nyamuk Aedes. Rerata suhu di kelurahan Karangklesem berkisar $18^{\circ} \mathrm{C}-31^{\circ} \mathrm{C}$ dengan rerata kelembaban udara $70 \%$ $85 \%$. Seperti dinyatakan oleh Iskandar et al. 1985, Yotopranoto et al. 1998, Suroso 1983 dan Boesri et al. 1995 bahwa suhu dan kelembaban optimum pertumbuhan nyamuk berkisar antara $24,5^{\circ} \mathrm{C}-30^{\circ} \mathrm{C}$ dan $70 \%-89,5 \%$. Selain itu, ruangan yang sangat gelap dan 
lembab juga merupakan kondisi pertumbuhan optimal bagi nyamuk.

Hasil uji statistik Mann-Whitney U menunjukan bahwa jumlah telur nyamuk Aedes sp. nyata lebih tinggi ( $\mathrm{p}=$ $0,001)$ pada ovitrap tempurung kelapa daripada gelas kaca di Kota Purwokerto tahun 2007. Telur lebih banyak didapatkan dari ovitrap tempurung kelapa karena tempurung kelapa memiliki karakteristik yang sesuai untuk pertumbuhan telur, yaitu warna coklat tua cenderung gelap yang disukai nyamuk Aedes sp. untuk meletakkan telur (Suroso 1983). Permukaan dinding yang kasar, menyebabkan nyamuk lebih mudah meletakkan telur dan dapat mengatur sikap saat oviposisi. Tempurung kelapa memiliki kemampuan menyerap air, sehingga kondisi ovitrap lembab dan mengundang nyamuk meletakkan telur.

Kepadatan telur/larva Aedes sp. di dalam container, dipengaruhi oleh jenis, warna dan kemampuan container menyerap air. Container yang berdinding licin, terang dan tidak menyerap air seperti yang dimiliki oleh ovitrap gelas kaca, relatif kurang disukai oleh Aedes sp. Permukaan yang licin akan menyulitkan oviposisi nyamuk. Warna bening/terang ovitrap menyebabkan sumber cahaya dari sinar lampu atau sinar matahari memasuki dan menerangi isi ovitrap. Warna bening juga merupakan penghantar panas matahari, menyebabkan suhu dalam ovitrap mendekati atau sama dengan suhu lingkungan. Gelas kaca juga tidak menyerap air dibandingkan dengan tempurung kelapa, sehingga berpengaruh pada kelembaban ovitrap (Bond \& Fay 1969; dan Rozilawati et al. 2007).

Hasil penelitian ini sama dengan hasil penelitian Wahyuningsih et al. (2006) di Semarang yang mendapatkan bahwa ovitrap gelas kaca hitam memperlihatkan index ovitrap sebesar $30 \%$. Pada penelitian ini ovitrap gelas kaca bening memperlihatkan index ovitrap 32,2\%. Penggunaan ovitrap gelas kaca bening pada penelitian ini mendapatkan jumlah telur sebesar 1.858 butir, sedangkan penelitian Wahyuningsih et al. (2006) di Semarang mendapatkan jumlah telur sebanyak 1.835 butir. Terdapat persamaan index ovitrap dan jumlah telur yang dihasilkan pada penelitian ini dengan hasil penelitian waktu pengambilan telur pada penelitian ini sama dengan penelitian Wahyuningsih et al (2006) yaitu musim penghujan, yaitu bulan Mei 2007. Tetapi, hasil penelitian ini agak berbeda dengan hasil penelitian Wahyuningsih et al. (2008) di kota Purwokerto, yang mendapatkan hasil index ovitrap dengan gelas kaca hitam di kota Purwokerto sebesar $27 \%$, dan jumlah telur yang dihasilkan sebanyak 833 butir, lebih rendah dibandingkan dengan index ovitrap 32,2\% dan jumlah telur 1858 butir hasil penelitian ini. Pada penelitian Wahyuningsih et al. (2008), 
pengambilan telur di Purwokerto dilakukan pada saat musim kemarau yaitu bulan September 2006.

Terdapat pengaruh musim terhadap jumlah telur karena musim penghujan dapat menaikkan kelembaban nisbi udara. Nyamuk memerlukan kelembaban yang tinggi untuk hidup. Suatu daerah dengan kelembaban kurang dari 60\% akan memperpendek lama hidup nyamuk (WHO 2005). Kelembaban tinggi membantu nyamuk tetap bertahan hidup dan berkembang biak dengan baik. Selain itu, musim hujan dapat meningkatkan sampah yang menampung air hujan sehingga dapat menambah breeding places bagi nyamuk. Pada musim kemarau kemungkinan jumlah nyamuk menjadi lebih sedikit karena kelembaban turun dan sampah yang ada tidak menampung air sehingga telur dilapangan yang didapat menjadi lebih sedikit.

\section{KESIMPULAN}

Jumlah telur yang diperoleh dari ovitrap tempurung kelapa di kelurahan Karangklesem, Arcawinangun dan Kober 5 kali lebih banyak dibandingkan dengan telur dari ovitrap gelas kaca di tiga kelurahan yang sama (9328 dan 1858). Indeks ovitrap tempurung kelapa di tiga kelurahan mencapai $57 \%$, atau 1,8 kali lebih banyak dibandingkan dengan indeks ovitrap gelas kaca (32\%) di kelurahan yang sama. Terdapat perbedaan yang signifikan jumlah telur nyamuk Aedes sp. antara dua jenis ovitrap. Disarankan agar masyarakat memiliki kebiasaan tertib dalam membuang sampah karena tempat yang dapat menampung air akan menjadi breeding place potensial bagi nyamuk. Penyuluhan Dinas Kesehatan Kota dalam upaya PSN (pemberantasan sarang nyamuk), yakni upaya $3 \mathrm{M}$ (menutup, mengubur, menguras) sebaiknya dilakukan terhadap semua tempat penampung air baik yang buatan maupun alami.

\section{UCAPAN TERIMA KASIH}

Penulis mengucapkan terima kasih kepada Direktorat Jenderal Pendidikan Tinggi Depdiknas yang telah memberi kesempatan kepada kami dan telah memberikan kepercayaan dan pembiayaan sehingga penelitian ini dapat terlaksana dan terselesaikan dengan baik.

\section{DAFTAR PUSTAKA}

Boesri H, Suwaryono S, Yasid T, Sudipurwanto M. 1997. Kepadatan telur Aedes aegypti dan Aedes albopictus berdasarkan ketinggian daerah pemukiman di Jawa Tengah, Majalah Parasitologi Indonesia, Vol. 10 (1): p. 48 53.

Bond HA, Fay RW. 1969. Factor Influencing Aedes aegypti Occurrance in Containers. Mosq News, 29, 113-116.

Depkes RI. 1992. Petunjuk Teknis Pemberantasan Nyamuk Penular Penyakit DBD, Ditjen P2M \& PLP, Jakarta. 
Iskandar A, Sudjain, Sanropie J, Nuidja M, Slamet AR, Sembiring M, Firdaus. 1985. Pemberantasan Serangga dan Binatang Pengganggu. Pusdiknakes, Jakarta.

Jackman JA. and Olson JK. 2008. Mosquitoes and the Diseases They Transmit.

http://www.skeetersquad.com/art icles/mosquitos_and the disease s_they_transmit.

Rozilawati H, Zairi J, Adanan CR 2007. Seasonal abundance of Aedes albopictus in selected urban and suburban areas in Penang, Malaysia Tropical Biomedicine 24 (1): 83-94.

Suroso T 1983. Tinjauan Keadaan dan Dasar-dasar Dalam Pemberantasan Demam Berdarah di Indonesia, Sub, Dit, Arbovirus Dit, P2B2 Direktorat P3M, Ja-karta.

Wahyuningsih NE, Dharmana E, Kusnawati E 2006. Survei nyamuk Aedes spp, di 3 Kecamatan di Kota Semarang tahun 2006, Seminar Nasional dan Simposium Strategi Pengendalian Nya- muk sebagai Vektor Tular Penyakit dalam upaya peningkatan kualitas Kesehatan Masyarakat, FKM UNDIP, Depkes, APNI, Semarang, 31 Agustus.

Wahyuningsih NE, Dharmana E, Kusnawati E, Sulistiawan A, Purwanto E 2008. Survei Aedes spp, di 3 Kota, Semarang Purwokerto dan Yogyakarta 2006, J, Entomol, Indon, Vol, 5 No, 1 , 45-49.

WHO 2005. Tropical Disease Research, Making health research work for poor people, $P R O G$ RESS 2003-2004, Seventeenth Programme Report.

WHO. Dengue and dengue haemorrhagic fever, The Villain Aedes Aegypti, http://www,who, int/mediacentre/factsheets/fs117/ en/. diakses 23 Juli 2008.

Yotopranoto S, Rosmanida S, Sulaiman. 1998. Dinamika Populasi Vektor pada Lokasi dengan Kasus Demam Berdarah Dengue yang Tinggi di Kotamadya Surabaya. Majalah Kedokteran Tropis Indonesia. Vol 9: No. 1 -2. 